\title{
Processing of Sour-Sweet Slices of Red Beet (Beta Vulgaris L.)
}

\author{
Karl Kaack \\ Aarhus University, Kirstinebjergvej 10, 5792 Aarslev, Denmark
}

\begin{abstract}
Uniform cylindrical and long beetroots in at least two size classes are necessary in order to produce slices with a firm and brittle texture using a minimum amount of energy and control with cooking time, temperature and peeling depth that is crucial. The steepest part of the firmness equation during cooking determines the velocity of temperature increase towards the root centre and the optimum brittleness occurs on the shallow part of the cooking curve. The purple and yellow colorants are degraded according to first order kinetic mechanism both during cooking and cooling. Peeling depth depends on heating and cooling rate that may be controlled efficiently. The colour change depends on oxygen availability and some of the degraded colorants may be regenerated using a nitrogen atmosphere by cooking, slicing and packing. Degradation rate of colorants may increase by interaction with mineral ions and may be counteracted using antioxidants and the colorants are degraded by light and combinations of light and oxygen may decrease the level of colorants seriously especially by high temperature. Beetroots contain peroxidases and polyphenol oxidases that may promote oxidation of the colorants until the temperature cause inactivation of these enzymes. Cooking and pasteurization of beetroot cubes in one step increased colour stability because oxygen not is available inside the beetroot tissue. Degradation of polymeric carbohydrates during cooking may increase drained weight. Leaching of soluted compounds such as potassium, nitrate and especially losses of sucrose may be reduced considerably by reusing of the cooking water up to at least twenty times without any off flavour in the final product. During storage of glass jars with beetroot slices may the colorants be degraded if the products are stored in light and especially if the jars contain air spaces.
\end{abstract}

Keywords: betacyanin - betaxanthin - colour - dry matter - firmness - soluble solids.

\section{INTRODUCTION}

Growing of high quality red beet slices as described previously [1] depends significantly on a precise and successive sowing of beet seeds from medium May in accordance with the expected sum of the local daily degree days $=\Sigma\left[\left(\mathrm{T}_{\min }+\mathrm{T}_{\max }\right) 0.5-(4.5)\right]$ using the local minimum $\left(\mathrm{T}_{\min }\right)$ and [maximum temperature in $\left(\mathrm{T}_{\max }\right)$ registered by Danish Meteorological Institute (DMI) with basis temperature $4.5^{\circ} \mathrm{C}$. The red beet slices are packed successively into glass jars supplied with brine made from sugar, acetic acid and various spices depending on the market destinations. The preserved beetroot slices are served to some hot meals that include different kinds of meat, vegetables and cooked potatoes. Another popular use of preserved red beet slices is as a decoration and flavouring ingredient upon several kinds of open rye bread sandwiches. Colour, flavour, texture, slice diameter and thickness are among the most determining sensory quality characteristics. In that connection may it may be necessary to inactivate peroxidases and polyphenol oxidases that may promote oxidation of the colorants during cooking until the temperature cause inactivation of these enzymes [2]. Cooking and pasteurization of beetroot cubes in one step increased colour stability because oxygen not is available inside the beetroot tissue. Degradation of polymeric carbohydrates during cooking may increase drained weight. Leaching of soluted compounds such as potassium, nitrate and especially losses of sucrose may be reduced considerably by reusing of the cooking water up to at least twenty times without any off flavour in the final product. During storage of glass jars with beetroot slices may the colorants be degraded if the products are stored in light and especially if the jars contain air spaces.

Industrial processing of preserved beetroot slices include sorting, washing, cooking, peeling, slicing, packing, weighing, addition of brine, pasteurization, closing and labelling [3] and the brine contains sugar, vinegar and in some cases a few spices or pieces of onion rings. The pigments in red beet are betalaines encompassing purple betacyanines and yellow betaxanthines that from a chemical point of view are ammonium conjugates of betalamic acid with cyclo-dopa and amino acids or amines, which are compounds present in our diet [4]. The other diet components in preserved red beetroot slices are 
sucrose and acetic that also is naturally and very important components in the human biology [5]. Whole cooked, or boiled and preserved red beetroot are traditionally produced in two sizes from cylindrical beetroots with diameter 40-50 and 50-60 mm, that leave considerably amounts of smaller and larger beets, which may be used for processed other red beet products.

During storage of preserved beets a white precipitate very often appears at the bottom of the glass jars, which has concerned consumers. However, the major component in the precipitate is calcium oxalate due to high level of oxalic acid in the beetroots [6] and a relatively high level of calcium in the applied tap water [7].

Beetroots may be cooked or steamed continuously or by batches at $100-120^{\circ} \mathrm{C}$ for between 25 to 70 min depending on root size and root age probably because more time or higher temperature are necessary by increasing size and root age [8]. The major reason is that the contents primary cell wall components including lignins, pectins, hemicelluloses and celluloses increases with beetroot age [9] and the kinetics of thermal softening of beetroots may be considered as described previously [10, 11]. Cooking and peeling may result in leaching of water soluble compounds such as sucrose, potassium, and nitrate from beetroots as described earlier.

Therefore the aim of this research was to study the effects of cooking, cooling, cutting, aeration and storage on flavour, texture, colorants, sugar, calcium, potassium and nitrate on preserved beetroot slices in glass jars.

\section{MATERIALS MethodS}

Beetroots were harvested manually, the leaves were removed using a sharp kitchen knife and the major amount of soil were removed gently before the beetroots were transported to the processing facilities for washing by hand using tap water $\left(12{ }^{\circ} \mathrm{C}\right)$, weighing and mechanical sorting by diameter into roots with diameter $<40,40-60$ and $>60 \mathrm{~mm}$ in order to determine the yield of beetroots. The major part of the experiments in this research was carried out using size 40-50 $\mathrm{mm}$. Beetroot size were measured using a calliper gauge and beetroot weight was determined using a Sartorius weight (BP 310 S, Bie and Berntsen, Roedovre, Denmark), respectively. The beetroots applied in each experiment were mixed carefully and packed into four or ten kg net bags made of plastic and kept in cool storage at $1{ }^{\circ} \mathrm{C}$ and $98 \%$ relative humidity $(\mathrm{RH})$ until analysis and processing. Samples for analysis included raw materials that was frozen and stored at $-25^{\circ} \mathrm{C}$.

Four kg cylindrical beetroots from each experimental treatment were heat treated in water baths or cooked in a steam jacketed kettle (Oluf Brønnum, Metos Viking 12 CS, and Herlev, Denmark) with $40 \mathrm{~L}$ tap water for the stipulated time and temperature. Thereafter they were transferred into $40 \mathrm{~L}$ cold tap water and cooled to centre temperature below $18{ }^{\circ} \mathrm{C}$. Samples for determination of losses of sucrose, potassium and nitrate were taken each ten minutes during cooking of 'Forono beetroots for 30 to $90 \mathrm{~min}$. The amount of each compound $\left(\mathrm{C}_{\mathrm{t}}\right)$, cooking time $(\mathrm{t})$ and surface area $(\mathrm{g})$ was used for determination of the leaching rate $\mathrm{K}=\left(\mathrm{C}_{\mathrm{t}}-\mathrm{C}_{\mathrm{t}-10}\right) / \mathrm{gt} \mathrm{mg} \mathrm{min}^{-1} \mathrm{~cm}^{-2}$ for each compound using that the weight of raw material $\mathrm{g}=1 \mathrm{~cm}^{2} \mathrm{~g}^{-1}$. Another series including successively cooking of 25 batches of 25 beetroot cylinders $(325 \mathrm{~g})$ at $100{ }^{\circ} \mathrm{C}$ in $1200 \mathrm{~mL}$ tap water using a $2 \mathrm{~L}$ bottle with electrical heating and equipped with a water cooler that eliminated water losses and kept the temperature constant. One $\mathrm{mL}$ processing liquid was exchanged with one $\mathrm{mL}$ tap water after each cooking of 25 beetroot cylinders.

Beetroot length was defined as the length from the cut surface to the beginning of the tap root. The average beetroot diameter was determined as the average diameter at $1 / 4,1 / 2$ and $3 / 4$ length from the cut surface obtained by removal of the leaves during harvesting. The root radius and length were applied for determination of the surface areas of raw $F_{\text {raw }}=2 \pi r_{r} l_{r}$ and cooked beetroots $F_{\text {cooked }}=2 \pi r_{c} l_{c} c^{2}$. Each replicate was carried out using 10 beetroots from the cultivar 'Forono'.

Removal of the peel that has been loosened during cooking was easy done using a peeling machine with a cylindrical drum, diameter $48 \mathrm{~cm}$ and length $110 \mathrm{~cm}$. The outside of the drum was 12 rotating rods $3 \mathrm{~cm}$ in diameter covered by hard drilled rubber using water beams $\left(10 \mathrm{~kg} \mathrm{~cm}^{-2}\right)$ from ten nozzles and a drum velocity $17 \mathrm{rpm}$. Average weight of the processed beets was $338 \mathrm{~g}$. Peeling losses was calculated on the basis of beetroot surface area $(\mathrm{F})$, volume $(\mathrm{V})$ and weight $(\mathrm{W})$, which make it possi-

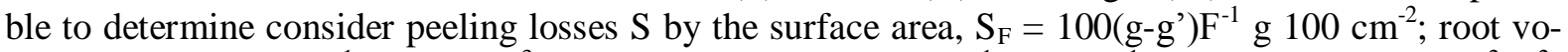
lume $S_{\mathrm{V}}=100\left(\mathrm{~g}_{\mathrm{g}} \mathrm{g}^{\prime}\right) \mathrm{V}^{-1} \mathrm{~g} 100 \mathrm{~cm}^{-}{ }^{3}$ and weight $S_{\mathrm{W}}=100\left(\mathrm{~g}-\mathrm{g}^{\prime}\right) \mathrm{g}^{-1} \mathrm{~g} 100 \mathrm{~g}^{-1}$, peel volume $\mathrm{S}=\pi \mathrm{l}\left(\mathrm{r}_{1}{ }^{2}-\mathrm{r}_{2}{ }^{2}\right)$ 
$\mathrm{cm}^{3}$ and the peeling depth $\mathrm{D}=\left(\mathrm{r}_{1}-\mathrm{r}_{2}\right) \mathrm{cm}$. Beetroot slices $6.8 \mathrm{~mm}$ in height or cubes with $6.8 \mathrm{~mm}$ edge were processed immediately after cooling using a kitchen cutter (Robot Coupe S.A., CL50, Mountceau Bourgogne, France). The cut materials were packed in $580 \mathrm{~cm}^{3}$ glass jars with $350 \mathrm{~g}$ cooled beetroot pieces and $250 \mathrm{~g}$ brine composed of $2 \mathrm{w} / \mathrm{w} \%$ acetic acid (Merck, Darmstadt, Germany), 36.6 w/w \% sucrose (Danisco A/S, Copenhagen, Denmark), $2 \mathrm{~g} \mathrm{~L}^{-1} \mathrm{Na}$-benzoate (Merck, Darmstadt, Germany), $2 \mathrm{~g} \mathrm{~L}^{-1}$ potassium sorbate (Applichem $\mathrm{GmbH}$, Darmstadt, Germany) and kept at $80{ }^{\circ} \mathrm{C}$. Immediately afterwards were the jars pasteurized and then cooled using tap water $\left(12{ }^{\circ} \mathrm{C}\right)$ and the products were kept on cool storage at $3{ }^{\circ} \mathrm{C}$ until analysis. Firmness of raw, cooked and preserved samples without brine were carried out using an Instron apparatus (Instron Ltd, Food Tester model 5565, High Wycombe, U K) equipped with a Kramer-shear cell and registering the maximum force ( $\mathrm{kg}$ ) to break $100 \mathrm{~g}$ red beet slices or cubes in the sample cell at piston velocity $20 \mathrm{~cm} \mathrm{~min}^{-1}$.

Drained weight of preserved beetroot slices or cubes was determined after draining of the beet materials for $3 \mathrm{~min}$ on a sieve (ASTA II, mesh 7, aperture $2.8 \mathrm{~mm}$ ) and samples of raw, cooked and drained red beet materials for chemical or physical analyses were obtained by maceration in a minimum of double distilled water or other liquids using a Waring blender (Waring Products B012-34-BL 99, New Hartford, USA). The colorants including betacyanins and betaxanthins were extracted from the macerated materials, diluted with $0.05 \mathrm{M}$ phosphate buffer $\mathrm{pH} 6.5$ (Merck, Darmstadt, Germany) and measurement absorbance at 476 and 538 and $600 \mathrm{~nm}$ in filtrated samples using a spectrophotometer (Shimadzu, MPS 2000, Kyoto, Japan) and the extinction coefficient 60.700 for betanin and 25.373 for vulgaxanthin by calculation according to the formulas presented by [12]. Surface color including lightness (L), greenness-redness (a) and blueness-yellowness (b) were measured using a Minolta Chroma Meter (CR 300, Osaka, Japan). Dry matter was determined by vacuum drying at $20 \mathrm{~mm} \mathrm{Hg}$ for 20 hours at room temperature $\left(20^{\circ} \mathrm{C}\right)$ if the dry material was used for further analytical measurements of organic compounds or in a heating cabinet at $80{ }^{\circ} \mathrm{C}$ for 20 hours by determination of minerals and dry matter only.

Water insoluble dry matter (Widm) was determined from $50 \mathrm{~g}$ macerated material weighed onto dried filters (S\&S 520S, $185 \mathrm{~mm}$ ), washing with boiling distilled water (Elgastat SB, BioSurplus, San Diego, USA) until complete removal of betanin and drying of the filters at $80{ }^{\circ} \mathrm{C}$ for 20 hours. Soluble solids $\left(\mathrm{g}_{\left.100 \mathrm{~g}^{-1}\right)}\right.$ were determined in filtrates from macerated samples of Red beet material using a refractometer (Bellingham + Stanley, RF M 800, Turnbridge Wells, Kent, UK). Determination of sucrose and glucose using gas liquid chromatography was initiated by treatment of $100 \mathrm{~g}$ Red beet cubes with $300 \mathrm{~g}$ double distilled water and transfer of $5 \mathrm{~g}$ macerate to dilution ten times with double distilled water. Then $1000 \mu \mathrm{L}$ extract were mixed with $100 \mu \mathrm{L}$ solution of trehalose in water $(2.50 \mathrm{~g}$ in 100 $\mathrm{mL}$ ) and diluted to $5 \mathrm{~mL}$ extracts with internal standard that was frozen to $-25{ }^{\circ} \mathrm{C}$ and dried in vacuum $(25 \mathrm{~mm} \mathrm{Hg}$ ) before addition of $500 \mu \mathrm{L}$ pyridine and $500 \mu \mathrm{L}$ Trisil to silylate the sugars. Separation and quantification of sugars were obtained using a Hewlett Packard 5840 A gas chromatograph equipped with a $2.5 \mathrm{~m}$ column (i.d. 1/8 inch) packed with 80/100 mesh OV-1, an HP7651 automatic sampler, FID detector at $300{ }^{\circ} \mathrm{C}$, air flow $300 \mathrm{~mL} \mathrm{~min}^{-1}$, hydrogen flow $30 \mathrm{~mL} \mathrm{~min}{ }^{-1}$, oven temperature $200-295^{\circ} \mathrm{C}$ increasing $4{ }^{\circ} \mathrm{C} \mathrm{min}^{-1}$, attenuation $2^{8}$, slope 2 , area rejection $10^{4}$, and $10 \mathrm{ml} \mathrm{min}^{-1}$ nitrogen as carrier gas. Six panel members age 20-40 evaluated texture properties of cooked beet slices five times during five successive days using a scale from 1 to 10 , where 1 is very soft and 10 is very hard. The taste panel also ranked 26 samples of cooked beetroot slices according to redness. The gas chromatographic measurement of oxalic acid was carried out using Pye Unicam 64 gas chromatograph combined with an integrator (Hewlett Packard 3370, Hillerød, Denmark) equipped with a stainless steel column (five m, 1/8 inch i.d.) packed with 80/100 mesh diatomite CT, 10 p.c. CW 20M. Injection temperature $250{ }^{\circ} \mathrm{C}$, column temperature $50-150{ }^{\circ} \mathrm{C}, 6{ }^{\circ} \mathrm{C} \mathrm{min}{ }^{-1}$, carrier gas flow $40 \mathrm{~mL} \mathrm{~min}^{-1}$, FID detector at $350{ }^{\circ} \mathrm{C}$, air flow $300 \mathrm{~mL}^{-1}$, hydrogen flow $30 \mathrm{~mL}^{-1}$, slope $0.1 \mathrm{mV}$ min-1 and injection of $10 \mu \mathrm{L}$ ester preparation. The concentration of oxalic acid was quantified using a standard curve produced daily.

The first cool storage experiment with processed beetroot slices processed from 'Formanova' included adjustment of brine $\mathrm{pH}$ to 4.1, 3.0, 3.6 and 3.4 using acetic acid and storage of the samples in cooling cabinets at $5,10,15$ and $20^{\circ} \mathrm{C}$ for $1,75,167,437,445$ and 635 days in the dark with two replicates. The effects of the treatments were measured by determination of the contents of betacyanin in the beetroot slices because they normally are served as slices only. The second experiment using 'Formanova` slices included studies of the effect of light air on lightness (L) and redness (a) of bee- 
troot slices packed in $540 \mathrm{~cm}^{3}$ glass jars packed with 10,20,30 and 40 beetroot slices combined with $50,100,150,200$ and $300 \mathrm{~mL}$ brine in two replicates. The jars were stored in a north facing window for two months (January and December) and included opening of the jars twice in a week in order to simulate praxis in a household where air are supplied by each opening of a jar exposed to scattered daylight from the window.

The statistical methods included linear and logarithmic regression, ranking, one-way and multiple ANOVA using a Statgraphic Statistical Package (Statistical Graphics, Version 4, Rockville, USA). Averages were separated using letters $\mathrm{P}<0.05$. Factor analysis included varimax rotation of normalized data and a Scree test were carried out according to [13, 14].

\section{RESUlTS AND DisCUSSION}

The content of betacyanin and vulgaxanthine in raw beets from the cultivar 'Forono' that was harvested at five dates from $5^{\text {th }}$ September to $31^{\text {st }}$ October and kept on cool storage at $3{ }^{\circ} \mathrm{C}$ for 82 days shows that the content of betacyanine was non-significantly different in samples from the five harvest times (Table 1), while the content of betaxanthin increased significantly from $76.9 \mathrm{mg} 100 \mathrm{~g}^{-1}$ after

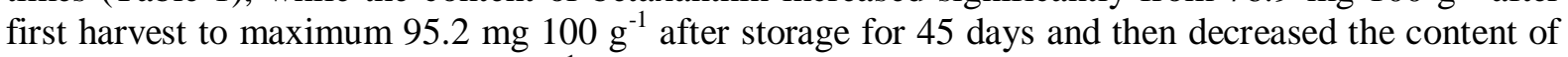

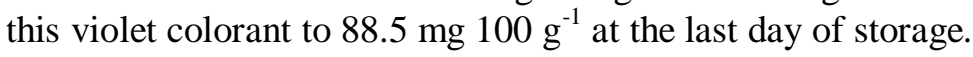

Table1. Effects of time on colorants, soluble solids, betaxanthin,

\begin{tabular}{|c|c|c|c|c|}
\hline Harvest, date & 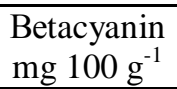 & $\begin{array}{l}\beta \text {-xanthin } \\
\text { mg } 100 \mathrm{~g}^{-1}\end{array}$ & $\begin{array}{l}\text { Soluble solids } \\
\text { g } 100 \mathrm{~g}^{-1}\end{array}$ & g $100 \mathrm{~g}^{-1}$ \\
\hline $5^{\text {th }}$ Sep & $110.4 \mathrm{a}$ & $76.9 \mathrm{~b}$ & $12.3 \mathrm{~d}$ & $2.7 \mathrm{c}$ \\
\hline $19^{\text {th }}$ Sep & $105.3 \mathrm{a}$ & $90.0 \mathrm{a}$ & $12.2 \mathrm{~d}$ & $2.9 b c$ \\
\hline $3^{\text {rd }}$ Oct & $105.8 \mathrm{a}$ & $90.1 \mathrm{a}$ & $13.4 \mathrm{c}$ & 3.0ab \\
\hline $17^{\text {th }}$ Oct & $104.0 \mathrm{a}$ & $95.2 \mathrm{a}$ & $13.8 \mathrm{~b}$ & $3.3 \mathrm{a}$ \\
\hline $31^{\text {st }} \mathrm{Oct}$ & $105.5 \mathrm{a}$ & $88.5 \mathrm{a}$ & $14.1 \mathrm{a}$ & $3.3 \mathrm{a}$ \\
\hline Days & 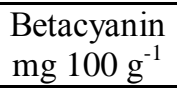 & $\begin{array}{c}\text { Betaxanthin } \\
\text { mg } 100 \mathrm{~g}^{-1}\end{array}$ & $\begin{array}{c}\text { Soluble solids } \\
\text { g } 100 \mathrm{~g}^{-1}\end{array}$ & $\begin{array}{c}\text { Widm } \\
\text { g } 100 \mathrm{~g}-1\end{array}$ \\
\hline 2 & $104.4 \mathrm{a}$ & $83.8 \mathrm{~b}$ & $13.0 \mathrm{~cd}$ & $3.0 \mathrm{ab}$ \\
\hline 19 & $106.5 \mathrm{a}$ & $88.8 \mathrm{ab}$ & $12.7 \mathrm{c}$ & $3.2 \mathrm{a}$ \\
\hline 32 & $105.6 \mathrm{a}$ & $95.5 \mathrm{a}$ & $13.3 \mathrm{ab}$ & $3.2 \mathrm{a}$ \\
\hline 45 & $107.0 \mathrm{a}$ & $87.7 \mathrm{ab}$ & $13.5 \mathrm{a}$ & 3.0ab \\
\hline 56 & $105.8 \mathrm{a}$ & $86.7 \mathrm{ab}$ & $13.3 \mathrm{a}$ & $2.8 \mathrm{~b}$ \\
\hline 71 & $106.6 \mathrm{a}$ & $87.9 \mathrm{ab}$ & $13.1 \mathrm{a}$ & $2.9 \mathrm{ab}$ \\
\hline 82 & $108.4 \mathrm{a}$ & $85.8 \mathrm{~b}$ & $13.3 \mathrm{a}$ & 3.0ab \\
\hline Min & 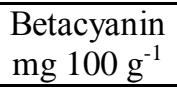 & $\begin{array}{c}\text { Betaxanthin } \\
\text { mg } 100 \mathrm{~g}^{-1}\end{array}$ & $\begin{array}{c}\text { Texture } \\
\mathrm{kg}\end{array}$ & \\
\hline 15 & $112.0 \mathrm{a}$ & $42.4 \mathrm{a}$ & $344 \mathrm{a}$ & \\
\hline 30 & 107.4 & $39.5 \mathrm{~b}$ & $196 \mathrm{~b}$ & \\
\hline 45 & $105.3 \mathrm{c}$ & $31.1 \mathrm{c}$ & $109 \mathrm{c}$ & \\
\hline 60 & $103.2 \mathrm{~d}$ & $26.3 \mathrm{~d}$ & $74 d$ & \\
\hline 75 & $99.2 \mathrm{e}$ & $20.5 \mathrm{e}$ & $66 \mathrm{e}$ & \\
\hline 90 & $93.6 \mathrm{f}$ & 17.1f & 69de & \\
\hline
\end{tabular}

Soluble solids and water insoluble dry matter increased significantly throughout the whole harvest period. The concentration of betacyanine was not significantly different throughout the storage period for the raw beets, while the content of vulgaxanthine increased significantly to a maximum after storage for 32 days and then decreased significantly until the last day of cool storage. The concentration of soluble solids had maximum after 45 days of storage, whereas water insoluble dry matter had a small maximum at 19 to 32 days of storage. During cooking decreased betacyanin, betaxanthin, texture and water insoluble dry matter (Widm) decreased significantly during cooking. In peeling experiment 1 using beetroots from the cultivar 'Forono` increased peeling losses significantly from 9.7a, to $11.3 \mathrm{~b}, 14.8 \mathrm{c}$ and $15.2 \mathrm{~d} \mathrm{w} / \mathrm{w} \%$ with harvest time from $2^{\text {st }}$ August to $7^{\text {th }}$ September without significant effect of cooking time from 30 to $90 \mathrm{~min}$. The peeling depths were $1.3 \mathrm{~mm}$ by cooking for $30 \mathrm{~min}$ and $2.0 \mathrm{~mm}$ for the remaining treatments and highest after preheating. Peeling losses (P) for 'Forono', 'Rød Valse', 'Unik' and 'Halanga' in peeling experiment 2 were on average 12.6a, 12.1ab, 12.1ab and $11.5 \mathrm{~b} \mathrm{~g} 100 \mathrm{~g}^{-1}$, respectively, and increased on average for these cultivars linearly with cooking time: $\mathrm{P}=9.3+0.0459 * \mathrm{~min} ; \mathrm{R}=0.78$ by cooking for $30,40,60,75 \mathrm{~min}$, respectively. The peeling experiment 3 with the cultivar 'Formanova` showed that peeling losses was 11.4, 17.1, 19.8, and $21.6 \mathrm{~g} 100$ 
$\mathrm{g}^{-1}$ by cooking for $30,45,60$ and $75 \mathrm{~min}$. On the basis of this research it may be concluded that peeling losses varies considerable between cultivars, increases by increasing cooking time and the peeling depth was $1-2 \mathrm{~mm}$.

Table2. Changes in firmness during cooking of whole beet roots and effects of cooking time and storage time on the texture

\begin{tabular}{|c|c|c|c|c|c|c|c|c|c|c|c|c|c|c|}
\hline $\begin{array}{c}\text { Harv- } \\
\text { est }\end{array}$ & \multicolumn{6}{|c|}{ Cooking time, min } & \multicolumn{8}{|c|}{ Storage, days } \\
\hline & 15 & 30 & 45 & 60 & 75 & 90 & 2 & 19 & 32 & 45 & 56 & 71 & 82 & 90 \\
\hline $5^{\text {th }}$ Sep & $312 \mathrm{c}$ & $167 \mathrm{c}$ & $89 d$ & $67 \mathrm{c}$ & $54 d$ & $50 \mathrm{c}$ & $\begin{array}{c}326 \\
b\end{array}$ & $348 \mathrm{a}$ & $358 \mathrm{a}$ & $\begin{array}{c}343 a \\
b\end{array}$ & $252 \mathrm{a}$ & $\begin{array}{c}339 a \\
b\end{array}$ & $\begin{array}{c}349 \\
\mathrm{a}\end{array}$ & $51 \mathrm{e}$ \\
\hline $\begin{array}{l}19^{\text {th }} \\
\text { Sep }\end{array}$ & $327 \mathrm{c}$ & $\begin{array}{c}183 b \\
c\end{array}$ & $104 \mathrm{c}$ & $77 b$ & $58 \mathrm{~b}$ & $58 \mathrm{~b}$ & $\begin{array}{c}169 \\
b\end{array}$ & $201 \mathrm{a}$ & $192 \mathrm{a}$ & $200 \mathrm{a}$ & $200 \mathrm{a}$ & $204 \mathrm{a}$ & $\begin{array}{c}205 \\
a\end{array}$ & $\begin{array}{c}54 d \\
e\end{array}$ \\
\hline $3^{\text {rd }}$ Oct & $351 b$ & $195 b$ & $\begin{array}{c}110 b \\
c\end{array}$ & $79 b$ & $\begin{array}{c}60 b \\
c\end{array}$ & $\begin{array}{c}60 b \\
c\end{array}$ & $95 b$ & $\begin{array}{c}108 \mathrm{a} \\
\mathrm{b}\end{array}$ & $110 \mathrm{a}$ & $108 \mathrm{a}$ & $110 \mathrm{a}$ & $117 \mathrm{a}$ & $\begin{array}{c}117 \\
\mathrm{a}\end{array}$ & $60 b$ \\
\hline $\begin{array}{l}17^{\text {th }} \\
\text { Oct }\end{array}$ & $369 a$ & $220 \mathrm{a}$ & $125 \mathrm{a}$ & $\begin{array}{c}82 a \\
b\end{array}$ & $63 a$ & $63 a$ & $72 \mathrm{c}$ & $75 b c$ & $\begin{array}{c}80 \mathrm{ab} \\
\mathrm{c}\end{array}$ & $80 \mathrm{abc}$ & $\begin{array}{c}79 a b \\
c\end{array}$ & $81 \mathrm{ab}$ & $84 a$ & $\begin{array}{c}58 b \\
c\end{array}$ \\
\hline $\begin{array}{l}31 \mathrm{st} \\
\text { Oct }\end{array}$ & $\begin{array}{c}366 a \\
b\end{array}$ & $216 a$ & $\begin{array}{c}118 \mathrm{a} \\
\mathrm{b}\end{array}$ & $89 a$ & $63 a$ & $63 a$ & $58 \mathrm{c}$ & $64 b$ & $63 \mathrm{bc}$ & $65 b$ & $67 a b$ & $66 b$ & $71 \mathrm{a}$ & $\begin{array}{c}63 a \\
b\end{array}$ \\
\hline & & & & & & & $54 \mathrm{de}$ & $60 b$ & $58 \mathrm{bc}$ & $60 \mathrm{~b}$ & $58 \mathrm{bc}$ & $60 b$ & $\begin{array}{c}63 a \\
b\end{array}$ & $66 \mathrm{a}$ \\
\hline
\end{tabular}

Table 3. Effect of cooking time on firmness, betanine, drained weight using raw materials from four cultivars $(n=4)$

\begin{tabular}{|c|c|c|c|c|c|c|c|c|}
\hline $\begin{array}{c}\text { Time, } \\
\text { min }\end{array}$ & Forono & Rød Valse & Unik & Halanga & Forono & Rød Valse & Unik & Halanga \\
\hline & \multicolumn{4}{|c|}{ Firmness, kg } & \multicolumn{4}{|c|}{ Betanine, mg $100 \mathrm{~g}^{-1}$} \\
\hline 0 & - & - & - & - & $101 \mathrm{fp}$ & 64as & $97 \mathrm{aq}$ & $82 \mathrm{ar}$ \\
\hline 30 & 160ap & $148 \mathrm{ar}$ & $144 \mathrm{ar}$ & $164 \mathrm{aq}$ & $119 \mathrm{a}$ & $56 \mathrm{cr}$ & $87 \mathrm{cp}$ & $80 \mathrm{bq}$ \\
\hline 40 & $132 \mathrm{bp}$ & $91 \mathrm{bq}$ & $83 \mathrm{br}$ & $97 \mathrm{bq}$ & $106 \mathrm{bp}$ & $60 \mathrm{bs}$ & $90 \mathrm{bq}$ & $77 \mathrm{cr}$ \\
\hline 50 & $91 \mathrm{cp}$ & $71 \mathrm{cq}$ & $65 \mathrm{cr}$ & $71 \mathrm{cq}$ & $115 \mathrm{bp}$ & $62 \mathrm{bs}$ & $72 \mathrm{gq}$ & $67 \mathrm{cr}$ \\
\hline 60 & $68 \mathrm{dp}$ & $59 \mathrm{dq}$ & $51 \mathrm{dr}$ & $59 \mathrm{dq}$ & 104ep & $51 \mathrm{es}$ & $86 \mathrm{cq}$ & $76 \mathrm{cr}$ \\
\hline 70 & 66dp & $7 \mathrm{eq}$ & $51 \mathrm{dr}$ & $51 \mathrm{er}$ & 108dp & $53 \mathrm{dr}$ & $79 \mathrm{fq}$ & $75 \mathrm{dq}$ \\
\hline 80 & $56 \mathrm{ep}$ & $49 \mathrm{fq}$ & $45 \mathrm{er}$ & $53 \mathrm{ep}$ & $111 \mathrm{cp}$ & $47 \mathrm{fs}$ & $84 \mathrm{dq}$ & \\
\hline \multirow[t]{2}{*}{90} & $54 \mathrm{ep}$ & $49 \mathrm{fq}$ & $45 \mathrm{er}$ & $44 \mathrm{fr}$ & $102 \mathrm{fp}$ & $46 \mathrm{fs}$ & $81 \mathrm{eq}$ & \\
\hline & \multicolumn{4}{|c|}{ Drained weight, g } & \multicolumn{4}{|c|}{ Water insoluble dry matter, g $100 \mathrm{~g}^{-1}$} \\
\hline 0 & & & & & $3.08 \mathrm{aq}$ & $2.84 \mathrm{ar}$ & 3.23ap & $3.08 \mathrm{aq}$ \\
\hline 30 & 399dp & $402 \mathrm{dp}$ & 408ap & $392 \mathrm{cp}$ & $2.37 \mathrm{bp}$ & $2.10 \mathrm{bq}$ & $2.53 \mathrm{bp}$ & $2.35 \mathrm{bp}$ \\
\hline 40 & $403 \mathrm{cp}$ & $407 \mathrm{cp}$ & 407ap & $401 \mathrm{bp}$ & $2.13 \mathrm{cq}$ & $2.00 \mathrm{cq}$ & $2.29 \mathrm{cp}$ & $2.11 \mathrm{cq}$ \\
\hline 50 & 408bp & $412 \mathrm{bp}$ & 407ap & 405bp & $2.07 \mathrm{dq}$ & $1.87 \mathrm{dq}$ & $2.16 \mathrm{dp}$ & $1.96 \mathrm{dq}$ \\
\hline 60 & 411ap & 410bp & 408ap & $405 \mathrm{bp}$ & $1.90 \mathrm{eq}$ & $1.99 \mathrm{cq}$ & $2.05 \mathrm{ep}$ & $1.92 \mathrm{eq}$ \\
\hline 70 & 410ap & 410bp & 411ap & 412ap & 190eq & $1.99 \mathrm{cq}$ & $2.05 \mathrm{ep}$ & $1.90 \mathrm{fq}$ \\
\hline 80 & 410ap & $411 \mathrm{bp}$ & 412ap & 409ap & $2.00 \mathrm{ep}$ & $1.83 \mathrm{eq}$ & 2.02ep & $1.83 \mathrm{gq}$ \\
\hline 90 & 411ap & 420ap & 415ap & 412ap & $1.79 \mathrm{fq}$ & $1.84 \mathrm{fq}$ & $2.00 \mathrm{fp}$ & $1.82 \mathrm{gq}$ \\
\hline
\end{tabular}

The firmness of beetroot decreased significantly with increasing cooking time after 2 days of storage (Table 2). During the next two storage periods increased the firmness at all cooking times until a maximum after 32 days of storage that was followed by significantly decreases to almost equal firmness at most of the storage days. It is remarkable that the firmness after occurrence of the maximums is significantly higher than the values after the first two storage times. It is obvious that the decrease in firmness with increasing cooking time occurred according to two first order reactions with the highest decrease immediately after start of cooking and with the lowest rate at the latest cooking times. Firmness, betacyanine and betaxanthin decreased significantly by cooking of beetroots from the four red beet cultivars 'Forono', Rød Valse', 'Unik', and 'Halanga' decreased significantly with cooking time. It is remarkable that the changes in texture in principle are almost similar, while the cultivar 'Forono' have a significantly higher content than the three cultivars 'Rød Valse', 'Unik' and 'Halanga`. The content of betaxanthin was also significantly higher in slices from 'Forono' in comparison to the other three cultivars, which may result in a less violet color by long cooking times. Data from sensory evaluation of beetroot softness showed that the point for softness was 9.8, 8.5, 7.1, 5.2 and 2.4 point after cooking of raw beetroots for $10,20,40,60$ and 90 min at $95{ }^{\circ} \mathrm{C}$. These data shows that firmness measured using a Cramer-shear cells are significantly correlated with sensory evaluation by trained panel members. Drained weight increased significantly with cooking time, while water insoluble dry matter (Widm) decreased significantly with cooking time (Table 3). The changes the 
physical and chemical structures in the cell walls, starches, proteins, hydrolysis of polymers, oxidation of colorants and losses of water soluble substances such as sugars, minerals, and amino acids that depends on structures in the beetroot slices including beetroot size. These processes leaves room for absorption of brine and exchange of compounds between beetroot and the cooking water that depends of time and temperature both by cooking, pasteurization and storage. The content of betacyanin, betaxanthin and drained weight was not affected by increasing pasteurization temperature and time, while firmness decreased significantly by increasing temperature and time at 70 to $95{ }^{\circ} \mathrm{C}$ for 10 to $60 \mathrm{~min}$.

Firmness decreased significantly from $148 \mathrm{~kg}$ to $117 \mathrm{~kg}$ by increasing pasteurization temperature and from 135 to 131 and $128 \mathrm{~kg}$ by pasteurization for more than ten minutes. An experiment with increased holding time resulted in significantly increasing in the content of betanin from $111 \mathrm{mg} 100 \mathrm{~g}$ betacyanin $100 \mathrm{~g}^{-1}$ without holding time to $113 \mathrm{mg} 100 \mathrm{~g}^{-1}$ by cooking for $60 \mathrm{~min}$ using holding time (Table 6). Cooking using holding time resulted in significantly higher content of beta xanthine for up to $240 \mathrm{~min}$. Purging of open jars with sliced beetroots using oxygen resulted in significantly decreases of both betacyanines and betaxanthin, whereas purging with nitrogen reduced the degradation rates of betaxanthin significantly.

If oxygen were purged through the samples of sliced beetroots disappeared more than fifty per cent of betanin within half an hour, whereas vulgaxanthin increased to a significantly higher level during the first $30 \mathrm{~min}$ using holding time for $30 \mathrm{~min}$. Data from measurement of the surface colour of red beet slices showed that vulgaxanthin concentration decreased significant during cooking causing increasing redness and decreasing the yellowness. According to previous research decreased betacyanine 5,

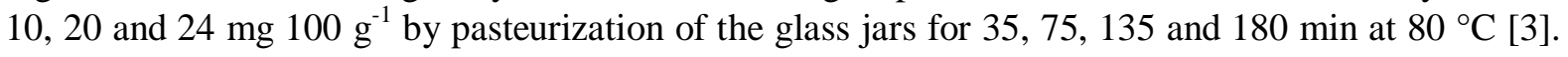
Cooking of raw cubes with $1 \mathrm{~cm}$ edge resulted in significantly increasing contents of betacyanin, betaxanthin and drained weight, whereas soluble solids was constant and firmness decreased significantly (Table 8). Significantly increasing "pasteurization" temperature for raw cubes resulted also in a higher contents of betacyanin, betaxanthin and drained weight while soluble solids was almost constant and firmness decreased significantly. The taste panel ranked 26 samples of cooked beetroot slices according to redness that resulted in a significantly positive and linear relation between rank number and concentration of betanin ranked by spectroscopy: rank $=0.31+0.272$ betacyanin $\left(R^{2}=94.1 \%\right)$

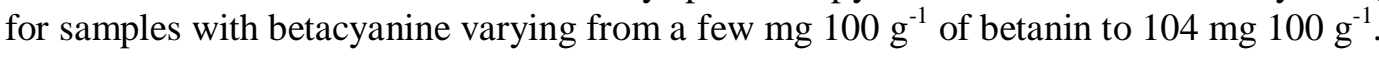

An experiment with combined cooking time and holding times for detached beetroot slices after cooking resulted in significant decreases of betacyanin and betaxanthin, whereas the content of betaxanthin increased by leaving the slices detached in up to $240 \mathrm{~min}$ which may be due to chemical changes in the cooked beetroots (Table 5).

Table 4. Effect of harvest time and beetroot diameter on drained weight and firmness.

\begin{tabular}{|c|c|c|c|c|c|c|}
\hline & \multicolumn{7}{|c|}{ Cooking time, min } \\
\hline Size, mm & 15 & 30 & 45 & 60 & 75 & 90 \\
\hline \multicolumn{7}{|c|}{ Drained weight, $\mathrm{g}$} \\
\hline 35 & $352 \mathrm{a}$ & $379 \mathrm{a}$ & $382 \mathrm{a}$ & $383 \mathrm{a}$ & $384 \mathrm{a}$ & $384 \mathrm{a}$ \\
\hline 40 & $347 \mathrm{~b}$ & $371 \mathrm{~b}$ & $378 \mathrm{a}$ & $383 \mathrm{a}$ & $381 \mathrm{a}$ & $384 \mathrm{a}$ \\
\hline 50 & $340 \mathrm{~d}$ & $366 \mathrm{c}$ & $373 \mathrm{~b}$ & $381 \mathrm{a}$ & $381 \mathrm{a}$ & $384 \mathrm{a}$ \\
\hline \multicolumn{7}{|c|}{ Firmness, kg } \\
\hline $35-40$ & $294 \mathrm{a}$ & $117 \mathrm{~b}$ & $75 \mathrm{c}$ & $61 \mathrm{~d}$ & $54 \mathrm{e}$ & $53 \mathrm{a}$ \\
\hline $40-50$ & $336 \mathrm{a}$ & $165 \mathrm{~b}$ & $78 \mathrm{c}$ & $66 \mathrm{~d}$ & $56 \mathrm{e}$ & $53 \mathrm{f}$ \\
\hline $50-60$ & $377 \mathrm{a}$ & $219 \mathrm{~b}$ & $76 \mathrm{c}$ & $76 \mathrm{c}$ & $59 \mathrm{~d}$ & $63 \mathrm{e}$ \\
\hline
\end{tabular}

Table 5. Effects of pasteurization temperature $(n=5)$ and time $(n=6)$ on betanin, vulgaxanthin, firmness and drained weight $(n=5)$.

\begin{tabular}{|c|c|c|c|c|c|c|c|c|c|}
\hline${ }^{\circ} \mathrm{C}$ & $\begin{array}{c}\text { Betanin } \\
\mathrm{mg} 100 \\
\mathrm{~g}^{-1} \\
\end{array}$ & $\begin{array}{l}\text { Vugaxanthin, } \\
\text { mg } 100 \mathrm{~g}^{-1}\end{array}$ & $\begin{array}{c}\text { Firmness } \\
\mathrm{kg}\end{array}$ & $\begin{array}{c}\text { Drained } \\
\text { weight, } \\
\mathrm{g}\end{array}$ & $\begin{array}{l}\text { Time } \\
\text { min }\end{array}$ & $\begin{array}{c}\text { Betanin, } \\
\mathrm{mg} 100 \\
\mathrm{~g}^{-1}\end{array}$ & $\begin{array}{l}\text { Vugaxanthin, } \\
\text { mg } 100 \mathrm{~g}^{-1}\end{array}$ & $\begin{array}{c}\text { Firmness, } \\
\text { kg }\end{array}$ & $\begin{array}{c}\text { Draine } \\
\text { weight } \\
\mathrm{g} \\
\end{array}$ \\
\hline 70 & $103 a$ & $25 a$ & $148 \mathrm{a}$ & $375 a$ & 10 & $111 \mathrm{a}$ & $24 a$ & $135 \mathrm{a}$ & $577 a$ \\
\hline 75 & $102 a$ & $24 \mathrm{a}$ & $148 \mathrm{a}$ & $375 a$ & 20 & $113 a$ & $25 \mathrm{a}$ & $131 \mathrm{~b}$ & $376 a$ \\
\hline 80 & $107 \mathrm{a}$ & $25 \mathrm{a}$ & $131 \mathrm{~b}$ & $374 a$ & 40 & $110 \mathrm{a}$ & $24 a$ & $131 \mathrm{~b}$ & $375 a$ \\
\hline 85 & $109 a$ & $24 a$ & $122 \mathrm{c}$ & $373 a$ & 60 & $112 \mathrm{a}$ & $25 a$ & $132 b$ & $373 a$ \\
\hline 90 & $106 a$ & $24 \mathrm{a}$ & $123 \mathrm{c}$ & $374 a$ & 90 & $106 \mathrm{~b}$ & $26 \mathrm{~b}$ & $128 b$ & $369 a$ \\
\hline 95 & $107 \mathrm{a}$ & $26 a$ & $117 d$ & $373 a$ & & & & & \\
\hline
\end{tabular}


The contents of sucrose, potassium and nitrate in seven samples of the cooking water taken during cooking of 'Forono' beetroots for 30 to 90 min increased exponentially with cooking time. The amount of each compound $\left(\mathrm{C}_{\mathrm{t}}\right)$, cooking time $(\mathrm{t})$ and surface area $(\mathrm{g})$ was used for determination of the leaching rate $\mathrm{K}=\left(\mathrm{C}_{\mathrm{t}}-\mathrm{C}_{\mathrm{t}-10}\right) / \mathrm{gt} \mathrm{mg} \mathrm{min} \mathrm{cm}^{-1}$ for each compound using that the weight of raw material $\mathrm{g}=1 \mathrm{~cm}^{2} \mathrm{~g}^{-1}$. It was found that $\mathrm{K}_{\text {sucrose }}=0.247, \mathrm{~K}_{\text {potassium }}=0.007872$, and $\mathrm{K}_{\text {nitrate }}=0.0011774 \mathrm{mg}$ $\min ^{-1} \mathrm{~cm}^{2}$ with standard deviations $0,000458,0,000458$ and $0,000105 \mathrm{mg} \mathrm{min}^{-1} \mathrm{~cm}^{2}$ and the amounts of leached compounds was 16,17 and $6 \%$ of the contents in the raw beetroots.

Leaching of sucrose from 'Formanova' beetroot cylinders with diameter $2.5 \mathrm{~cm}$ and length $7.0 \mathrm{~cm}$ resulted in accumulation of sucrose in the boiling liquid according to fig 4 . The cylinders were produced one by one single beetroots using a cork drill and the cooking time was 30 min. Figure sucrose shows that the concentration of sucrose in the boiling water increased stepwise with the number of samples of beetroot cylinders and after 25 samples was the concentration equal to the sucrose concentration in the beetroots (Fig Sucrose). The content of eluted betanine in cooking water was significantly correlated to the content of eluted sugar: $\mathrm{mg}$ betanine/g sugar $=-0.92+0.633 \mathrm{~g}$ sugar $(\mathrm{R}=0.938)$. The average content of water insoluble dry matter increased significantly with increasing harvest time

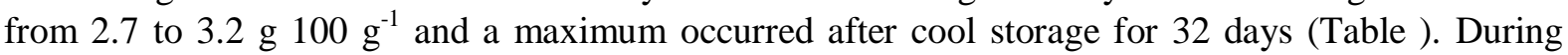

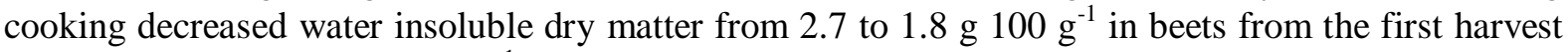

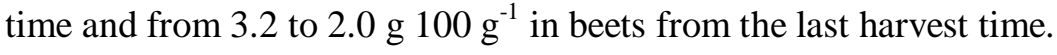

The content of water insoluble dry matter in the four cultivars 'Forono', Rød Valse', 'Unik' and Halanga' were significantly different $3.08 \mathrm{~b}, 2.84 \mathrm{c}, 3.23 \mathrm{a}$ and $3.08 \mathrm{~b} \mathrm{~g} 100 \mathrm{~g}^{-1}$ and for the cultivar Forono' decreased water insoluble dry matter significantly with cooking time from 0 to $90 \mathrm{~min}$ $\left(\log _{10} \mathrm{VUT}=0.509-0,002432 \mathrm{~min}(\mathrm{R}=0.949)\right.$. Beet root slices were packed in brine with $\mathrm{pH}$ at four levels and kept on storage temperature at four temperatures for up to 635 days in the dark in order to study the effects on the content of betacyanin using beetroot slices processed using the cultivar 'Formanova' as raw material in two replicates. An experiment with studies of the effects of light and oxygen on lightness (L) and Redness (a) defined using the CIE color system included beetroot slices packed in glass jars with varying number of beetroot slices combined with varying amounts of brine in two replicates. The jars were stored in a north facing window for two months (January and December) and included opening of the jars in order to simulate praxis in a household where oxygen from the air are supplied by each opening of a jar and scattered light from the window reached all glasses equally.

These data shows the large difference in concentrations between cultivars [20, 22] and the considerable proportion between betacyanines and betaxanthines in red beets [20, 21, 22]. The yellow color compounds in red beetroots are betaxanthins including betaxanthin I and II encompassing from 36 to

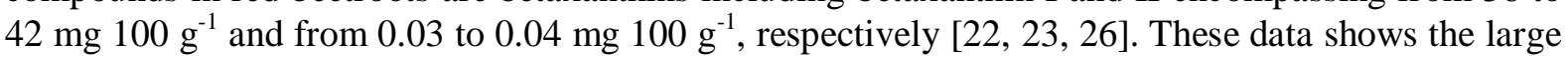
difference in concentrations of betacyanines and betaxanthines between cultivars [20, 22]. Previous research has shown that betacyanin content in raw beetroots varied from 27 to135 mg betanin $100 \mathrm{~g}^{-1}$ $[20,21,22]$. On the basis of these data it was concluded that the contents of colorants in beetroots harvested and stored was satisfactory because the obtained surface color was very attractive. Soluble

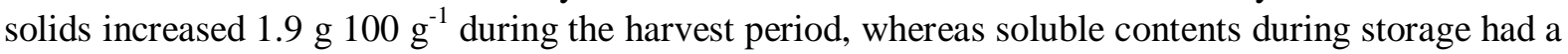
maximum after 3 months of storage.

\section{DISCUSSION}

Changes in degradation of betacyanine, vulgaxanthin, sugars and water insoluble dry matter during the harvest and storage period may be due to changes in biochemical and physiological processes [17].

Increasing harvest and cooking time increased peeling losses, while cooking temperature not affected losses of peel while stepwise cooling reduced peeling losses.

The peeling losses varied significantly between red beet cultivars and increasing peeling losses may decrease the contents of colorants that are highest in the outmost layer of the beetroots and highest in the beetroot tip [1].

Modification of beetroot texture determined as firmness depends significantly on gelatinization of the number and size of the starch granules partially hydrolyses of hemicelluloses and protopectins after 
depolymerization and is determined of the effects of temperature and cooking time duration that varies with food components, vegetable, cultivar and season [18].

Firmness of beetroots slices decreased significantly by each step from cooking for 15 to 90 min from about 370 to $50 \mathrm{~kg}$ and the firmness increased significantly with later harvest time and longer storage time (Table firmness). The rate of softening beetroot tissue during cooking is consistent with two first order kinetic mechanisms causing changes in the structure and chemical composition of the interlamellar layer between plant cells walls $[10,11,14,15,18]$. The decreases in firmness measured using the Instron apparatus were parallel to the decrease in firmness measured using the trained sensory panel and these changes are in accordance with previous research with cooking of red beetroots [3, 30].

The changes in texture during cooking are related to changes in microscopic structures and molecular architecture of the cell wall made up of cellulose fibrils imbedded in a matrix consisting of pectins, hemicelluloses, proteins, lignins, lower molecular weight solutes and water that increase during degradation of the red beet tissue by cooking [9,31]. By ordinary heating of beetroots is water used for hydrolysis of fiber components including cellulose, hemicellulose, lignin, non-cellulosic carbohydrates that also is included in alcoholic non-soluble residues from red beet [32]. Research in the effects of gamma irradiation on red beet tissue showed increased cell wall stiffness and caused chemical changes in the composition of alcohol insoluble material including lignin, cellulose, non-cellulosic carbohydrates, degree of methylation and acetylation, protein, hydroxyprolin, tyrosine, carbohydrates, uronic acid and pectin $[9,33]$. Such changes could explain the increases in drained weight because the rapid changes in cell wall composition could result in more space for the brine containing $24.2 \mathrm{w} / \mathrm{w} \%$ soluble solids that even may result in decreases in cell volume because of shrinking of vacuoles and cell membranes. During the growth and storage periods occurs incorporation of lower molecular weight solutes and water, pectins, hemicelluloses, proteins and lignins into the cell walls that increases in size [9] and therefore increased the average firmness of cooked beetroot slices significantly with harvest and storage time.

The content of betacyanins in cooked beetroots increased during the first part of the cooking time and decreased thereafter in the remaining cooking time according to first order kinetics [22, 35, 37]. This increase may be due to generation of betanin from already present compounds such as cyclo-dopa and betalamic acid that is promoted by organic and inorganic acids [21, 26]. As found previously have betacyanins been reported to be $[10,37,41]$ betaxanthins both at room temperature $[20,24,26]$. The thermos stability of betacyanin in beet juice and in beet puree was greater than observed with model systems, which means that presence of red beetroot tissue may improve colorant stability [35]. Betacyanines were less stable at $\mathrm{pH} 3$ than 5 and most stable between $\mathrm{pH} 4$ and 5 , whereas betaxanthines was much less stable than betacyanines as found in this research [20]. The decreases in content of colorants during heating as found in this research may be of serious concern within the canning industry because the reduction in colorants are known to be significantly higher by canning that are carried out at about $120{ }^{\circ} \mathrm{C}$ in comparison to that blanching and cooking normally are carried out at $85-90{ }^{\circ} \mathrm{C}$ and at $100{ }^{\circ} \mathrm{C}$, respectively $[18,19]$. Small increases in coloration from betacyanin during the first steps in blanching and canning of beetroots has been found previously [21, 41] and may be related to release of colorants by separation of the betacyanin molecule. Another possibility may be production of mono-, di- and trimethylacetate ester of betanin with acetic acid as found previously [26]. During pasteurization using temperatures from 70 to $95^{\circ} \mathrm{C}$ for 10 to 90 minutes resulted in decreasing firmness whereas this part of the processing not affected the contents of colorants very much while firmness decreased significantly with increasing temperature.

Another important result is that drained weight increases by this kind of processing as found previously [8]. During pasteurization at $80{ }^{\circ} \mathrm{C}$ for 75 min decreased betanin from 48.7 to $39.1 \mathrm{mg}^{100 \mathrm{~g}^{-1} \text { and }}$ in samples from the tree factories decreased betanin on average from 106.2 to $56.9 \mathrm{mg} 100 \mathrm{~g}^{-1}$, whe-

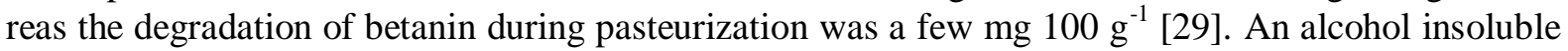
residue from beetroots may include cellulose $(26 \mathrm{w} / \mathrm{w} \%)$, non-cellulosic carbohydrates $(52 \mathrm{w} / \mathrm{w} \%)$, uronic acids $(14 \mathrm{w} / \mathrm{w} \%)$ and $5.9 \mathrm{w} / \mathrm{w} \%$ lignin [30]. The first storage experiment with cool storage of processed beetroot slices with $\mathrm{pH}$ adjusted brine to 4.1, 3.9, 3.6 and 3.3, at 5, 10, 15 and $20^{\circ} \mathrm{C}$ for 1 , $75,167,437,446$ and 635 days in the dark showed that the content of betacyanin in preserved red beet slices processed using the cultivar 'Formanova' as raw materials decreased with decreasing $\mathrm{pH}$ and increasing time in accordance to first order kinetic degradation. The content of in betacyanin due 
to $\mathrm{pH}$ at the beginning of the experiment was $61,64,67$ and $69 \mathrm{mg} 100 \mathrm{~g}^{-1}$ that decreased to $50,47,44$, $40 \mathrm{mg}$ betacyanin $100 \mathrm{~g}^{-1}$ beet root slice, which may be considered as satisfactory after two years of cool storage.

The experiment with studies of the effects of light and oxygen on lightness (L) and Redness (a) defined using the CIE color system included beetroot slices packed in $100 \mathrm{~cm}^{3}$ glasses with $10,20,30$ and 40 beetroot slices combined with 50,100,150, 200 and $300 \mathrm{~mL}$ brine in glass jars with two replicates. The jars were stored in a north facing window for two months (January and December) and included opening of the jars twice a week in order to simulate praxis in a household where oxygen from the air are supplied by each opening of a jar and scattered light from the window reached all glasses equally. Supply of light resulted in significantly decreased beetroot lightness from 16.4a to $14.6 \mathrm{~b}$ in comparison to redness that increased from $16.1 \mathrm{~b}$ to $19.2 \mathrm{a}$. A higher number of beetroot slices from 10 to 40 and a higher supply of brine from 50 to 300 reduced beetroot lightness significantly $16.9 \mathrm{a}$ to $13.6 \mathrm{~d}$ and increased redness from $13.7 \mathrm{~b}$ to $43.8 \mathrm{a}$. Increases in the amount of brine from 50 to $300 \mathrm{ml}$ resulted in a decreasing lightness from 16.1a to $15.2 \mathrm{~b}$ and increased redness from $17.0 \mathrm{c}$ to 32.0a. Leaching of sucrose from 'Formanova' beetroot cylinders $2.5 \mathrm{~cm}$ in diameter and $7.0 \mathrm{~cm}$ long were produced one by one from single beetroots using a cork drill and the cooking time was 30 min. The experiment included successively cooking of 25 batches of 25 beetroot cylinders $(325 \mathrm{~g})$ at 100 ${ }^{\circ} \mathrm{C}$ in $1200 \mathrm{~mL}$ tap water using a $2 \mathrm{~L}$ bottle with electrical heating equipped with a water cooler that eliminated water losses and kept the temperature constant.

One $\mathrm{mL}$ processing liquid was exchanged with one $\mathrm{mL}$ tap water after each cooking of 25 beetroot cylinders. The average weight of raw beets was $300.1 \mathrm{~b}$, cooked $(262.9 \mathrm{c})$ and preserved (308.9a) cylinders were significant different because the average loss by cooking was $32.2 \mathrm{~g}$ and the increase was $40.0 \mathrm{~g}$ after packing and storage. The losses may be beetroot liquid with extractable solutes such as sucrose, minerals, colorants and water that increase may by brine. Acetic acid decreased the half life time of betacyanin [31], whereas citric acid and EDTA increased half life time of betacyanin, which may be due to sequestering of betacyanine $[19,26,32,35,37,41]$. The first cooking of five samples of each 25 cylinders resulted in $267.2 \mathrm{~g}$ cooked beetroot cylinders and $304.8 \mathrm{~g}$ preserved beetroot cylinders and the concentration of the sugar and betacyanin in the cooking bottle were $2.4 \mathrm{w} / \mathrm{w} \%$ and

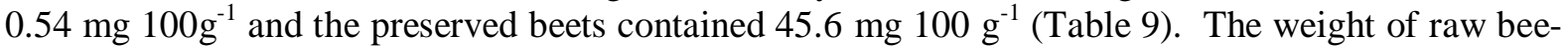
troot cylinders was not significant different after cooking of 25 samples, while small significant differences occurred for cooked and preserved beetroots. The level of sucrose and betanin in boiling water increased the sugars to $10.2 \mathrm{w} / \mathrm{w} \%$ and to $6.1 \mathrm{mg}$ betanin $100 \mathrm{~g}^{-1}$ and the content of betanin in the preserved cylinders increased from 45.6 to $63.0 \mathrm{mg}$ betanin $100 \mathrm{~g} \mathrm{~g}^{-1}$ after processing of 25 batches in one lot of cooking water. The amount of sugar in the boiling liquid may be written: $g$ sucrose $100 \mathrm{~g}^{-1}$

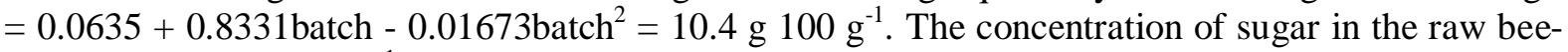

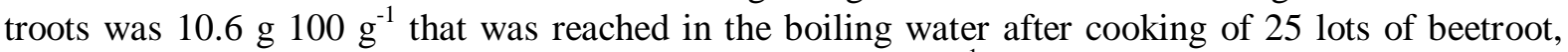
whereas the concentration of betanin only was $6.1 \mathrm{mg}^{0} 100 \mathrm{~g}^{-1}$ in the last lot because both colorants were degraded by cooking of beetroots at $100{ }^{\circ} \mathrm{C}$ (Table 9). The results from measurement of sucrose in the cooking water by cooking of whole beetroots at $100{ }^{\circ} \mathrm{C}$ and cooling in tap water and determina-

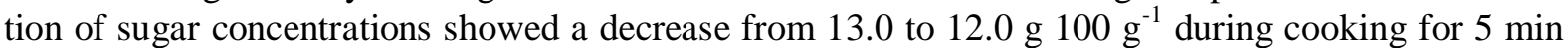

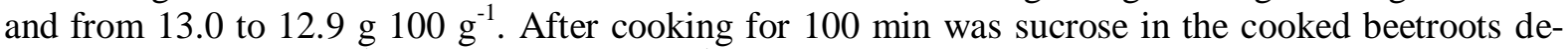

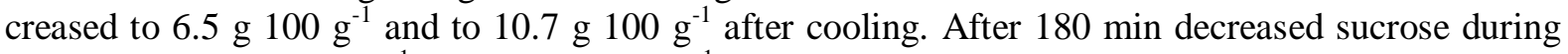

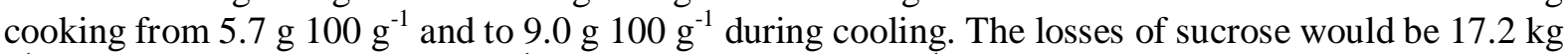
$\mathrm{t}^{-1}$ by cooking for $75 \mathrm{~min}, 12 \mathrm{~kg} \mathrm{t}^{-1}$ after $45 \mathrm{~min}$ and $8.8 \mathrm{~kg} \mathrm{t}^{-1}$ after 30 min (Table 1). After cooking of 10 batches in the same water would the losses be $2.3,3.0$ and $3.4 \mathrm{~kg} \mathrm{t}^{-1}$ only. On the basis of this may be concluded that cooking of an increasing number of beetroots in the same water will decrease losses of sucrose and betanin significant and reduced leaching into the rivers.

Heating in aqueous medium gelatinizes starch granules, partially hydrolyses hemicelluloses and solubilizes protopectins after depolymerization, modifying texture of these products and otherwise depend the effect of heat treatment the specific conditions of temperatures and duration on vegetable food components, depends on crop, cultivar and season [33]. Regeneration of the colorants may be obtained using antioxidants $[41,57,76]$ or by establishment of a nitrogen atmosphere as shown in (Table Purg 9. The percentage betacyanin regenerated decreased with increasing degradation before treatment with regenerating compounds [41] and regeneration may depend on temperature, $\mathrm{pH}$, type of buffer solution, and presence of oxygen $[44,50]$. Regeneration was improved under anaerobe conditions [35] and isobetanin produced during blanching and canning were regenerated within 10 hour 
from processing [21]. Using ascorbic acid, isoascorbic acid, metaphosphoric acid and gluconic acid caused reduction in the losses of betanin or increase regeneration of betanin [21, 41, 42]. Yellow pigments are regenerated by addition of glutamine [35]. Betacyanines may also be regenerated using betalamic acid, cyclodopa-5-O-glycosied and both degradation and regeneration increased with rising temperature [10].

Red beets contain peroxidases and polyphenol oxidases $[2,36,52,53]$ and other enzymes that degrade betacyanin during cooking. Unfortunately may it take up to 30-40 min before they are inactivated by cooking $[52,53]$. In this research was the temperature at 4, 5, 6 and $7 \mathrm{~cm}$ depth 90, 82, 76, $70{ }^{\circ} \mathrm{C}$ after cooking for $20 \mathrm{~min}$ at $95{ }^{\circ} \mathrm{C}$. Results from cooking and pasteurization of raw peeled beetroot cubes $\left(1 \times 1 \times 1 \mathrm{~cm}^{3}\right)$ in brine with sugar and acetic acid (Table 6) shows that betacyanin and betaxanthin increases significant both during cooking and pasteurization and firmness decreases as expected according to the results above in table 1 and 2. The increases in betacyanin and betaxanthin with cooking up to 90 min may be due to synthesis of the two colorants whereas the firmness decreases as fond previously). Synthesis of betacyanin and betaxanthin seem also to occur during the first 30 min, while the contents of both colorants decreases significantly during the remaining part of cooking and pasteurization.

Table 6. Effects of purging with nitrogen and oxygen on betanin and vulgaxanthin $(n=6)$

\begin{tabular}{|c|c|c|c|c|c|c|c|}
\hline \multirow[t]{2}{*}{ Colorant } & \multirow[t]{2}{*}{ Gas } & \multicolumn{6}{|c|}{ Treatment } \\
\hline & & 0 & 30 & 60 & 90 & 120 & 240 \\
\hline Betanin, mg $100 \mathrm{~g}^{-1}$ & $\mathrm{O}_{2}$ & $52 b$ & $22 b$ & $6 \mathrm{c}$ & $3 d$ & $3 d$ & $3 d$ \\
\hline “ & $\mathrm{N}_{2}$ & $52 \mathrm{a}$ & $53 a$ & $47 \mathrm{~b}$ & $42 b$ & $42 b$ & $24 \mathrm{c}$ \\
\hline Vulgaxanth. mg $100^{-1}$ & $\mathrm{O}_{2}$ & $56 b$ & $66 a$ & $45 c$ & $28 \mathrm{~d}$ & $19 \mathrm{e}$ & $14 f$ \\
\hline “ & $\mathrm{N}_{2}$ & $59 \mathrm{~b}$ & $72 \mathrm{a}$ & $69 a$ & $62 \mathrm{a}$ & $56 b$ & $34 \mathrm{c}$ \\
\hline
\end{tabular}

Firmness decreased significant with processing time and temperature as expected on the background of the previous experiments with cooking and pasteurization. Soluble solids were not affected, whereas drained weight increased significant from 358.2 to $382.6 \mathrm{~g}$ corresponding to $9.1 \mathrm{w} / \mathrm{w} \%$ increase using brine with $24.2 \mathrm{w} / \mathrm{w} \%$ soluble solids that may contribute to the increased drained weight.

Processing of beet root materials in small cubes may reduce the time to obtain maximum temperature and inactivation of enzymes in very short time in comparison to cooking beetroots with diameter 40$60 \mathrm{~mm}$ and this reduction in time may result in earlier inactivation of the enzyme that catalyze oxidation of betacyanin and the final result may be increased content of betacyanin. Based on these results it was concluded that cooking of red beet cubes $\left(1 \times 1 \times 1 \mathrm{~cm}^{3}\right)$ may result in inactivation of polyphenol oxidases and peroxidases that reduced the concentration of betacyanin by oxidation and cause physical and chemical changes in the beetroot tissue that may increase the uptake brine with a high sucrose concentration and result in a significant increase in drained weight of beet root tissue. Increases in water insoluble dry matter (Widm) with harvest and storage may promote water binding and increase drained weight.

Table 7. Effects of cooking and pasteurization on quality characteristics

\begin{tabular}{|c|c|c|c|c|c|c|c|c|c|c|c|}
\hline $\begin{array}{l}\text { Cooking } \\
\text { time, min }\end{array}$ & $\begin{array}{c}\text { Betanin } \\
\text { mg } 100 \\
\mathrm{~g}^{-1}\end{array}$ & $\begin{array}{l}\text { Vulgaxanthin } \\
\mathrm{mg} 100^{-1}\end{array}$ & $\begin{array}{c}\text { Firmness } \\
\mathrm{kg}\end{array}$ & $\begin{array}{c}\text { Soluble } \\
\text { solids } \\
\text { g } 100^{-1}\end{array}$ & $\begin{array}{l}\text { Drained } \\
\text { weight } g\end{array}$ & $\begin{array}{c}\text { Pasteurizing } \\
{ }^{\circ} \mathrm{C}\end{array}$ & $\begin{array}{c}\text { Betanin } \\
\text { mg } 100 \\
\text { g- }^{1}\end{array}$ & \begin{tabular}{|c|} 
Vulga- \\
xanthin \\
mg 100 \\
$\mathrm{~g}^{-1}$ \\
\end{tabular} & $\begin{array}{c}\text { Firmness, } \\
\mathrm{kg}\end{array}$ & \begin{tabular}{|c|}
$\begin{array}{c}\text { Soluble } \\
\text { solids } \\
\mathrm{g} 100 \mathrm{~g}^{-} \\
1\end{array}$ \\
\end{tabular} & $\begin{array}{c}\text { Drained } \\
\text { weight } \\
\text { g }\end{array}$ \\
\hline \multicolumn{6}{|c|}{ Cooking } & \multicolumn{6}{|c|}{ Pasteurization } \\
\hline 15 & $96.4 \mathrm{c}$ & $83.0 \mathrm{e}$ & $393.0 \mathrm{a}$ & $24.4 \mathrm{a}$ & $347.0 \mathrm{~d}$ & 75 & $98.8 \mathrm{~d}$ & $98.8 \mathrm{c}$ & $377.8 \mathrm{a}$ & $24.2 \mathrm{a}$ & $350.8 \mathrm{e}$ \\
\hline 30 & $108.0 \mathrm{~b}$ & $90.2 \mathrm{~d}$ & $316.4 \mathrm{~b}$ & $24.4 \mathrm{a}$ & $360.6 \mathrm{c}$ & 80 & $108.8 \mathrm{~b}$ & $108.9 \mathrm{a}$ & $331.2 b$ & $24.3 \mathrm{a}$ & $356.4 d$ \\
\hline 45 & $108.8 \mathrm{~b}$ & $90.6 \mathrm{c}$ & $254.2 \mathrm{c}$ & $24.3 \mathrm{a}$ & $366.7 b$ & 85 & $109.2 b$ & $109.2 \mathrm{a}$ & $264.4 \mathrm{c}$ & $24.0 \mathrm{a}$ & $363.8 \mathrm{c}$ \\
\hline 60 & $110.0 \mathrm{a}$ & $91.6 b$ & $194.8 \mathrm{~d}$ & $24.1 \mathrm{a}$ & $373.2 \mathrm{a}$ & 92 & $104.9 \mathrm{c}$ & $104.0 \mathrm{~b}$ & $201.4 d$ & $23.7 \mathrm{a}$ & $370.0 \mathrm{~b}$ \\
\hline 90 & $110.4 \mathrm{a}$ & $95.2 \mathrm{a}$ & $157.2 d$ & $24.0 \mathrm{a}$ & $376.2 \mathrm{a}$ & 98 & $112.9 \mathrm{a}$ & $103.0 \mathrm{~b}$ & $140.8 \mathrm{e}$ & $24.8 \mathrm{a}$ & $382.6 \mathrm{a}$ \\
\hline
\end{tabular}

The concentration of soluble solids, vulgaxanthin and water insoluble dry matter was similar in beetroot slices processed using beets with diameter 30-40, 40-50 and 50-60 mm, while betanin decreased significant by increasing diameter, which may be due to a general higher concentration in smaller beetroots compared to larger beetroots (Table 6). Drained weight of beetroot size 30-39 mm was significant highest in comparison to drained weight of beetroot slices with diameter 50-59 mm. Changes in 
firmness during processing decreased significant with time up to 60 min and firmness increased significant with increasing slice diameter.

Data from cooking of red beets from four cultivars showed that firmness was significantly highest for 'Forono' and significantly lowest for roots from 'Halanga' (Table 7). Therefore would the use of energy during cooking to equal firmness be the lowest for 'Unik' followed by 'Rød Valse', 'Halanga' and 'Forono'. The concentration of betanin decreased during cooking with the highest concentration in 'Forono', followed by 'Unik', 'Halanga' and lowest in Rød Valse'. Which make it clear that the most intense colors may be obtained using 'Forono'. The concentration of vulgaxanthin followed the same pattern as betanin. However, vulgaxanthin disappeared almost by cooking for more than 50-60 $\min ($ Table 7).

Drained weight increased significant with cooking time during cooking with minimum for 'Halanga' during the first hour of cooking. The largest increase in drained weight was obtained by cooking of Red Valse` that increased $18 \mathrm{~g}$ in drained weight followed by 'Forono` with $12 \mathrm{~g}$, 'Halanga` with 10 $\mathrm{g}$ and 'Unik' with $7 \mathrm{~g}$ (Table 7).

Insoluble dry matter decreased significant with increasing cooking time and the losses of insoluble dry matter was $1.23,1.26$ and $1.29 \mathrm{~g}$ for 'Unik', 'Halanga', 'Forono' and $1.00 \mathrm{~g}$ for 'Rød Valse'. Increasing cooking time increased drained weight, while insoluble dry matter decreased and may increase the space for brine. Acetic acid decreased the half life time of betacyanin, whereas citric acid and EDTA increased half life time of betacyanin due to sequestering [40] (Pasch and von Elbe, 1979; [26] Herbach et al.2006). Ascorbic acid and isoascorbic acid enhanced the stability of betacyanin and betaxanthines [34] (Attoe and von Elbe, 1982; [77]Cai and Corke, 1999; [26] Herbach et al. 2006) and in some cases has isoascorbic acid a better effect on betanin than ascorbic acid.

The average concentration of soluble solids or sugars in four red beet cultivars Forono', 'Halanga', 'Rød Valse' and 'Unik' measured in three replicates of the samples from five harvest days and seven storage days. The average concentration of soluble solids and sugars measured using refractometry; the picrate method, gas liquid chromatography (GLC) and the enzyme electrode system were 12.5,

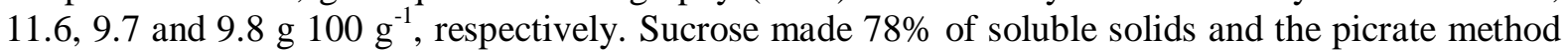
resulted in average in $1.85 \mathrm{w} / \mathrm{w} \%$ higher sucrose in comparison to the results obtained using the GLC method that resulted in the same level of sucrose as the enzyme electrode system. It was expected that the enzyme method would result in higher values than the GLC method because free glucose would be included using the enzyme electrode system. The explanation is that two peaks for glucose and fructose were missing for these compounds on the GLC chromatogram, which means that these sugars may occur in a very low concentration or be almost absent in beetroots. The higher values using the picrate method and refractometer may therefore be due to other compounds than sucrose, glucose and fructose.

Average soluble solids in the samples from the harvest and storage experiment were significant related to harvest time (soluble solids $=12.3+0.03437$ days; $r=0.99$ ), while sucrose not was as strongly related to harvest time as soluble solids (sucrose $=9.0+0.01215$ days; $\mathrm{R}=0.60$ ). Soluble solids was not significant related to storage time (soluble solids $=13.2+0.001953$ days; $R=0.28$ ), while sucrose was significant negatively related to storage time (sucrose $=9.8+0.009783 ; R=-0.93$ ). The explanation may be that the respiration processes are much needed during storage were starches are hydrolyzed to sugars and are the only source of energy during storage in comparison to the harvest period where energy are supplied by photosynthesis. The data presented regarding leaching rate of soluble compounds during cooking was highest for sucrose in comparison to the rates for potassium and nitrate and the very positive data obtained by recycling of the cooking liquid 25 times shows that a significantly amount of the sugar and other soluble compounds may be returned to be used recycled to the following cooking series. This may also reduce the amount of organic compounds and plant nutrients that are eluted to waste water treatment.

About $50 \%$ of the soluble sugars in red beetroot, carrot and turnip may be eluted during processing [78] that constitute the main energy source in vegetable diets [44] and red beetroot are rich in fibers, sugars, B-vitamins and has a high content of betalains that due to their high content of antioxidant is beneficial for human health [ $46,47,79]$. Extraction of betalaines may be carried out using a countercurrent diffusion apparatus with $0.50 \%$ citric acid solution as extraction liquid resulting in recovery of $75-90 \%$ of the betanin from beetroots into beetroot juice $[47,48]$ and application of electric pulses extraction technology may increase the recovery to about $98 \%$ recovery of betalaines [49]. Red bee- 
troot pigment may be extracted using water at $\mathrm{pH} 3-5$, solvent to beetroot ratio $(\mathrm{S} / \mathrm{B}) 1: 1-5: 1$, solvent initial temperature (ST) $30-70{ }^{\circ} \mathrm{C}$, and grinding time (GT, 2-10 $\mathrm{min}$ ) where the beetroot were grinded in the extraction liquid [50].

About $50 \%$ of the soluble sugars in red beetroot may be eluted during processing [78] that constitute the main energy source in vegetable diets [44] and red beetroot are rich in fibers, sugars, B-vitamins and has a high content of betalains that due to their high content of antioxidant that is beneficial for human health [47, 79, 80, 81] (Schwartz et al. 1980; [80] Kanner et al. 2001; [81].

Extraction of betalaines may be carried out using a counter-current diffusion apparatus with $0.50 \%$ citric acid solution as extraction liquid resulting in recovery of 75-90 \% of the betanin from beetroots into beetroot juice $[47,48]$ and application of electric pulses extraction technology may increase the recovery to about $98 \%$ recovery of betalaines [49]. Red beetroot pigment may be extracted using water at $\mathrm{pH}$ 3- 5, solvent to beetroot ratio (S/B) 1:1-5:1, solvent initial temperature (ST) 30-70 ${ }^{\circ} \mathrm{C}$, and grinding time (GT, 2-10 $\mathrm{min}$ ) where the beetroot were grinded in the extraction liquid [5]. Light promote degradation of betacyanines and betaxanthines [21, 35, 38] in the range 2200-4400 lux [38] and UV light are lowering the activation energy and the effects of UV light and air may even be cumulative [37]. In spite of these conclusions shows the data in table shows the data obtained in this research that the storage time for red beetroot slices are rather long if the glass jars are kept on cool storage where the temperature may be regulated in accordance with the optimum temperature for these product. A high amount of the violet betacyanine and the yellow betaxanthin showed that a satisfactory quality was obtained after a storage time up to 635 days if the storage temperature is kept at temperatures from 5 to $20^{\circ} \mathrm{C}$. The effects of light are negligible under anaerobic conditions [56, 66]. Presence of light in the head space increased darkening of beet puree [5] and betacyanine was completely destroyed by $100 \mathrm{~h}$ UV irradiation or using $100 \mathrm{krad}$ gamma irradiation [6]. The changes of the surface color on slices stored for two months at room temperature with light and exchange of head space air by opening and turning of the slices. The changes of color increased against higher lightness and increased redness with the amount of slices and brine that may be due to liquid in the jars and especially by increases in the content of betacyanine.

\section{REFERENCES}

[1] Kaack, K. (2016). Raw materials for processing of sour-sweet slices of red beetroot. Int. J. Forestry and Hort. 2: 19-30.

[2] Wasserman, B. P., Eiberger, L.L., and Guilfoy, M.P. (1984). Effect of hydrogen peroxide and phenolic compounds on horseradish peroxidase-catalyzed decolorization of betalain pigments. J. Food Sci. 49, 536-538.

[3] Kaack, K. 1977a. Changes in content of color substances in red beets during growth, storage, and during the industrial processing of red canned beets. Danish J. Plant Soil Sci. 81, 165-170.

[4] Moreno, D.A., C. Garcia-Vigueragil, J.I. Gill and A.G. Gil-Izçuierdo 2008: Betalains in the era of global agri-food science, technology and nutritional health. Phytochem. Rev. 7, 261-280.

[5] de Azeredo, H.M.C. 2009: Betalaines: properties, sources, applications, and stability - a review. Int. J Food Sci Technol 44, 2365-2376.

[6] Adrianse, A. and Robbers, J.E. (1969). Über eine modifizierte Gesamtoxalatbestimmung in Gemü-sen. Z Lebensm Unters Forsch 141, 158-160.

[7] Kaack, K. 1988c: White precipitate in red table beets. Danish J. Plant Soil Sci. 92, 329-334.

[8] Kaack, K. 1988a: Effects of sowing date, harvest time and storage on raw red beet quality and pro cessing requirements. Danish J. Plant Soil Sci. 92, 313-324.

[9] van Buren, J.P. 1979: The chemistry of texture in fruits and vegetables. J. Text. Stud. 10, 1-23.

[10] Huang, Y.T. and M.C. Bourne 1983: Kinetics of thermal softening of vegetables. J. Text. Stud. $14,1-9$.

[11] Kaack 1988d. Leaching of water soluble soluble substances during cooking of red beets (BetaVulgaris L.) Danish J. Plant Soil Sci 92, 335-338.

[12] Nilsson, T.1970: Studies into pigments in beetroot. Lantbrukshögskolans Annaler, 36, 179-210.

[13] Überla, K. 1971: Faktorenanalyse. Springer, New York.

[14] Sharma, S. 1996: Applied multivariate techniques, Wiley, New York pp. 99-143. 
[15] Bourne, M.C. and J.C. Moyer 1968: The extrusion principle in texture measurement of fresh peas.Food Technol. 22, 1013-1018.

[16] Wyler, H., G. Vincenti, M. Mercier, Sassu G. and A.S. Dreiding, 1959. Zur Konstitution des Randenfarbstoffes Betanin. Helv Chim Acta, 42: 1696-1698.

[17] Wyler, H. and A.S. Dreiding, 1961. Über Betacyanin, die stickstofhältigen Farbstoffe der Centrospermen. Experientia 17: 23-25.

[18] Habib, A.T. and H.D. Brown 1956: The effect of oxygen and hydrogen-ion concentration on color changes in processed beets, strawberries and raspberries. Proc. Am. Soc. Hort. Sci. 68, 482-490.

[19] Han, D., S.J. Kim, S.H. Kim and D.M. Kim 1998: Repeated regeneration of degraded red beet juice pigments in the presence of antioxidants. J Food Sci 63, 69-72.

[20] Sapers, G.M. and J.S. Hornstein 1979: Varietal differences in colorant properties and stability of red beet pigments. J. Food Sci 44, 1245-1248.

[21] von Elbe J. H. Schwartz, S.J. Hildenbrand, D.E 1981. Loss and regeneration of betacyanin pigment during processing of red beets. J. Food Sci. 46, 1713-1715.

[22] Gasztonyi M.N. Daood H., Hájos M. T. Biacs P. 2001. Comparison of red beet (Beta Vulgaris conditiva) varieties on the basis of their pigment components. J Sci Food Agric 81, 932-933.

[23] Mabry, T.J. 1966. The betacyanins and betaxanthines. In Comparativ Phytochemistry (ed. T. Swain, 231-244).

[24] Singer, J.W. and J.W. von Elbe 1980: Degradation rates of vulgaxanthine I J Food Sci 45, 489 491.

[25] Kujala TS, Vinkola MS, Klika KD, Lonen JM, Pihjla K (2002) Betalains and phenolics composit-ions of four beetroot (Beta vulgaris) cultivars Eur Food Res Technol 214,505-510.

[26] Herbach, K.M., F.C. Stintzing and R. Carle 2004: Impact of thermal treatment on color and pigment pattern of red beet (Beta vulgaris L.) J Food Sci 69, C491-C498.

[27] Shannon, S., Bourne M.C. 1971. Firmness measurement of processed table beets. J Texture Stud 2:230-239.

[28] Rao, M.A. Kenny, J.F. Shannons S. Bourne M.C. (1977). Firmness and thermal conductivity of red beets in storage. J. Food Process Eng. 1:259-267.

[29] Kaack, K. 1977b: Changes in content of color substances during production of canned sweetsour red beets. Danish J. Plant Soil Sci. 81, 171-177.

[30] Saguy, 1979. Thermostability of red beet pigments (Betanine and Vulgaxanthin-I: influence of $\mathrm{pH}$ and temperature. J. Food Sci. 44, 1554-1555.

[31] Micard, V., C.M.G.C. Renard and J.F. Thibault 1996: Enzymatic saccharification of sugar-beet pulp. Enzyme Microbiol. Technol, 19, 162-170.

[32] Latorre, M.E. Attoe, E.L. and J.H. von Elbe 1985: Oxygen involvement in betanine degradation: effect of antioxidants. J. Food Sci. 50, 106-110.

[33] Salunkhe, D.K, Desai, B.B. (1984) Postharvest biotechnology of fruits, CRC press, Boca Raton.

[34] Latorre, M.E., P.R. Bonelli, A.M. Roajas and Gerschensom L.N. (2012). Microwave inactivation of red beet (Beta vulgaris L. var. conditiva) peroxidase and polyphenoloxidase and the effect of radiation on vegetable tissue quality. J Food Engineering 109, 676-684.

[35] Czapski, J. 1985: The effect of heating conditions on losses and regeneration of betacyanins. Z. Lebensm. Unters. Forsch. 180, 21-25.

[36] Czapski, J. 1990: Heat stability of betacyanins in Red beet juice and in betanin solutions. Z. Lebensm. Unters. Forsch. 191, 275-278.

[37] Huang, A.S. and J.H. von Elbe 1985: Kinetics of the degradation and regeneration of betanine. J. Food Sci. 50, 1115-1120 and 1129.

[38] von Elbe, J.H., S.J. Schwartz, and B.E. Hildenbrand 1981: Loss and regeneration of betacyanin pigments during processing of red beets. J. Food Sci. 46, 1713-1715.

[39] Lusas, E.W., A.C. Rice and K.G. Weckel 1960: Changes in the color of canning beets: I. Changes during growth and processing: 2. Effects of variables in processing on the color of canned beets. 3. Effects of additives on color of canned beets. Research Bulletin 218, 1-23. University of Wisconsin-Madison, US. 
[40] Pasch JH; von Elbe (1979) Betanin1 stability and degradation-structural and chromatic aspects. J. Food Sci. 71, R41-R50.

[41] Ravichandran, K, Saw NMMT Mohdaly, AAA, Gabr, AMM, Kastell, A, Riedel, H, Cai, Z, Knorr, D, Smetanska, I. (2011) Impact processing of red beet on betalain content and antioxidant activity. Food Res Int. 50:670-675.

[42] Kanner, J., Harel, S., Grant, R. 2001: Betalains- A new class of dietary cationized antioxidants. J. Agric. Food Chem. 49, 5178-5185.

[43] López et al 2009, N., E. Puétolas, S. Condón, J. Raso and I. Álvares 2009: Enhancement of the solid-liquid extration of sucrose from sugar beet (Beta vulgaris) by pulsed electric fields, LWT Food Sci.Technol. 42, 1674-1680.

[44] Bilyk, A. and M. Howard 1982: Reversibility of thermal degradation of betacyanines under the influence of isoascorbic acid. J. Agric. Food Chem. 30, 906-908.

[45] Lee, Y.N. and N.I. Smith 1979: Blanching effect on polyphenol oxidase in table beets. J. Food Sci. $4,82-83$.

[46] Huang, A.S. and J.H. von Elbe 1986: Stability comparison of two betacyanine pigments - amaranthine and betanine. J. Food Sci. 51, 670-674.

[47] Kaack, K 1988b: Quality assessment of cylindrical red beet (Beta vulgaris L.). Danish J. Plant Soil Sci. 92, 325-327.

[48] von Elbe, J.H., I. Maing, and C.H. Amundson 1974. Color stability of betanine. J. Food Sci. 39, 334-337.

[49] Huang, K. 1988: Leaching of water soluble substances during cooking of red beets (Beta vulgaris L.). Danish J. Plant Soil Sci. 92, 335-338.

[50] Huang, A.S. and J. H. von Elbe 1987. Effect of $\mathrm{pH}$ on the degradation and regeneration of beta nine. J. Food Sci. 52: 16891693.

[51] Gerschenson 2012: Microwave inactivation of red beet (Beta vulgaris L. var conditiva) peroxidase and polyphenoloxidase and the effect of radiation on vegetable tissue quality. J. Food Eng. 109, 676-684.

[52] Lee, Y.N. and R.C. Wiley 1981: Betalaine yield from a continuous solid-liquid extraction system as influenced by raw product, post-harvest and processing variables. J. Food Sci. 46, 421- 424.

[53] Pasch, J.H. and von Elbe, J.H. 1979: Betanine stability in buffered solutions containing organic acids, metal cations, antioxidants, or sequestrants. J. Food Sci. 44, 72-74.

[54] Ravicandra K, Saw NMMT, Mohdaly AAA, Gabr AMM, Kastell AMM, Riedel H, Cai Z, Knoor DS, Smetanska I (2011) Impact of processing of red beet on betalain content and antioxidant activity. Food Res. Int. 50:670-675.

[55] Rao, M.A., Kenny J.F., Shannon S. and Bouerno M.C.1977: Firmness and thermal conductivity of red beets in storage. J. Food Proc. Eng. 1, 259-267.

[56] Rice, P. and J.D. Selman 1984: Technical note: Apparent diffusivities of ascorbic acid in peas during water blanching. J Food Technol. 19, 121-124.

[57] Schneberger, R., R. Stahl and M. Loncin 1975: Experimentelle Bestimmung der Diffusionskoefficienten einiger Wasserlöslicher Vitamine in Wasser. Lebensm. Wiss. Technol. 8, 222-224.

[58] Schwatzberg, H.G. 1975. Mathemathical analysis of solubilitization kinetics and diffusion in foods. J. Food Sci. 40, 211-213.

[59] Knorr, D, Smetanska, I201 Impact of processing red beet on betalain content and antioxidant activity. Food Res Int 50, 670-675.

[60] Martinez-Parra, J. and R. Muúnoz 2001: Characterization of betacyanin oxidation catalyzed by a peroxidase from Beta vulgaris L. roots. J. Agric. Food Chem. 49, 4064-4068.

[61] Aurstad, K. and K. Dahle 1973: The effects of heat treatment, UV and gamma radiation on some beetroot pigments. Z. Lebensm. Unters. Forsch. 151, 171-173.

[62] Latorre, M.E., P. Narzaz, A.M. Rojas, A.M. and L.N. Gershenson 2010: Effects of gamma irradiation on biochemical and physico-chemical parameters of fresh-cut Red beet (Beta vulgaris $\mathrm{L}$. var. conditiva) root. J. Food Eng. 88, 178-181. 
[63] Attoe, E.L. and J.H. von Elbe 1985. Oxygen involvement in betanin degradation: effects of antioxidants. J. Food Sci. 50:106-110.

[64] Govind J. Kapadia, G. Subba Rao (2012) Anticancer Effects of Red Beet Pigments Red Beet Biotechnology pp 125-154.

[65] Attoe, E.L. and J.H. von Elbe 1981: Photochemial degradation of betanine and selected anthocyanins. J. Food Sci. 46, 1934-1937. 